\title{
Kewajiban Perpajakan Wajib Pajak Badan Berdasarkan Tarif Umum Pph Badan Tahun 2020 (Studi Kasus Pada PT. Kamilia Utama Sentosa Mataram)
}

\author{
Suprianto ${ }^{* 1}$, Sarifudin $^{2}$, Diah rusminingsih ${ }^{3}$ \\ 1,2 Fakultas Ekonomi Dan Bisnis Universitas Mataram \\ ${ }^{3}$ STIKEN Jaya Negara Taman Siswa Malang
}

${ }^{*}$ Coresponding Email: pithikngguyu@gmail.com

\begin{tabular}{ll}
\hline \multicolumn{1}{c}{ Info Artikel } & \multicolumn{1}{c}{ ABSTRAK } \\
\hline Kata Kunci: & Penelitian ini mengambil judul “ Kewajiban Perpajakan Wajib \\
Bewajiban Perpajakan WP & Pajak Badan Badasarkan Tarif Umum PPh Badan Tahun 2020 \\
& ( Studi Kasus Pada PT. Kamilia Utama Sentosa Mataram”). \\
& Tujuannya untuk menganalisis koreksi fiskal dan PPh terutang \\
& dalam pemenuhan kewajiban perpajakan WP Badan berdasarakan \\
& Tarif Umum PPh Badan Tahun 2020. \\
& Penelitian ini dilaksanakan di PT. Kamilia Utama Sentosa di \\
& Mataram dengan penerapan metode kasus yaitu kasus yang ada pada \\
& PT. Kamilia Utama Sentosa terkait dengan Kewajiban perpajakan \\
& W P Badan mengacu pada peraturan pemerintah tentang tarif \\
& umum PPh Badan Tahun 2020. \\
& Pemennuhan Kewajiban Wajib Pajak Badan PT. Kamilia Utama \\
& Sentosa untuk tahun pajak 2020, yaitu Pemenuhan Kewajiban Wajib \\
& Pajak Badan terkait perhitungan, penyetoran, dan pelaporan SPT \\
& Tahunan telah dilaksanakan sesuai dengan ketentuan yang berlaku \\
& yaitu dengan penerapan tarif PPh Badan sebesar 22 \%. Hasil \\
& koreksi fiskal menunjukkan ada beda waktu dalam perhitungan \\
& terkait pengakuan biaya-biaya menurut undang-undang pajak. \\
& Koreksi positif menurut fiskal terjadi selisih sebesar Rp \\
& 13.674.428,- sedangkan Penghasilan Kena Pajak di laporan \\
& Laba/Rugi sebesar Rp 496.659.611, sehingga PPh terutang PKP \\
& yang mendapat Fasilitas (50 \% x 22 \% x PPh Yang mendapat \\
Fasilitas , yaitu PPh terutang sebesar Rp 34.062.397,- Setelah \\
dikurangi total kredit pajak yang telah disetorkan maka PPh \\
kurang/lebih bayar sebesar ( PPh terutang - Kredit Pajak ) yaitu Rp \\
34.062.397 - 61.917.344 = Rp 27.854.947,- (PPh yang lebih \\
dibayar). \\
Kelebihan bayar PPh badan PT. Kamilia Utama Sentosa dapat \\
diminta kembali atau di restitusi dan atau diperhitungkan pada tahun \\
pajak 2021 atau di kembalikan kelebihan pajak tersebut kepada PT. \\
Kamilia Utama Sentosa dengan mengajukan permohonan kepada \\
Direktorat Jenderal Pajak. \\
\hline
\end{tabular}




\section{Elastisitas - Jurnal Ekonomi Pembangunan \\ Vol. 3 No. 2, September 2021}

\section{PENDAHULUAN}

\section{Latar Belakang}

Indonesia merupakan salah satu negara yang mempunyai sumber pendapatan utama berasal dari pajak, dimana pajak merupakan suatu kewajiban menyerahkan sebagian dari kekayaaan ke kas negara yang disebabkan suatu keadaan, kejadian, dan perbuatan yang memberikan kedudukan tertentu, tetapi bukan sebagai hukuman, menurut peraturan yang ditetapkan pemerintah serta dapat dipaksakan, tetapi tidak ada jasa timbal balik dari negara secara langsung karena dipergunaknuntuk memelihara kesejahteraan secara umum. Pendapatan negara yang bersumber dari pajak mengalami peningkatan dari tahun ke tahun.

Menurut Menteri Keuangan Sri Mulyani Indrawati menyatakan, realisasi penerimaan pajak hingga 23 Desember 2020 sudah mencapai 1.019,56 triliun rupiah atau 85,65 persen dari target sesuai Perpres 72 Tahun 2020 sebesar 1.198,8 triliun rupiah. Dalam keterangan secara daring, Menteri Keuangan, Sri Mulyani Indrawati mengatakan penerimaan dari pajak, kepabeanan, cukai, dan penerimaan negara bukan pajak mengalami perubahan akibat tekanan yang besar. Realisasi penerimaan pajak itu mengalami peningkatan 8,45 persen dari capaian pada akhir November 2020 yang mencapai 925,34 triliun rupiah atau saat itu sudah mencapai 77,2 persen dari target sesuai Perpres 72/2020, ( Jakarta).

Untuk memaksimalkan peningkatan penerimaan pajak dari tahun ke tahun, dalam hal ini menteri keuangan dan Direktorat Jenderal Pajak telah mengeluarkan berbagai kebijakan perpajakan salah satunya adalah reformasi administrasi perpajakan yang semakin efektif dan efisien. Kebijakankebijakan tersebut dapatmeliputi perundangundangan KMK, SE-DJP. Satu kebijakan yang paling dianggap efisien dan efektif yaitu kebijakan tentang penyampaian SPT melalui e-filling .Ketentuan kewajiban e-Filing untuk $\mathrm{PPh}$ 21/PPh 26 ini ditetapkan melalui Peraturan Menteri Keuangan (PMK) Nomor 9/PMK.03/2018, yang berlaku sejak 1 April 2018.
Disisi lain mengingat pemahaman wajib pajak mengenai tata cara dan ketentuan perpajakan yang sering kali menjadi sebuah permasalahan dalam memenuhi kewajiban perpajakannya dan terjadinya perubahanperubahan peraturan perpajakan yang membuat semakin kompleks dan detailnya aturan pajak yang harus ditaati oleh masyarakat dalam hal ini oleh wajib pajak, Direktorat Jenderal Pajak memberikan kelonggaran dan kesempatan kepada Wajib Pajak untuk meminta pihak lain yang memahami masalah perpajakan sebagai kuasa Wajib Pajak untuk dan atas namanya membantu Wajib Pajak dalam melakukan kewajiban perpajakan. Dalam hal ini keajiban perpajakan dilakukan oleh wajib pajak orang pribadi maupun uajib pajaki badan (UP Badan) terutama yang melakukan kegitan usaha seperti PT. Kamilia Utama Sentosa merupakan perusahaan yang bergerak di bidang instalasi listrik dan beralamat di Jln. Segara Anak No. 45 Ampenan Kota Mataram. Prusahaan ini melaksakan pekerjaan proyek-proyek pemerintah mapun swasta baik melalui tender maupun pengadaan material untuk kebutuhan kantor pemerintah maupun BUMN seperti Dinas Pekerjaan Umum, Perusahaan Listrik Negara dan lain sebgainya.

Sesuai Perpu no 1 tahun 2020 pemerintah telah menurunkan tarif pajak penghasilan badan dari sebelumnya sebesar 25 persen menjadi 22 persen untuk tahun tahun pajak 2020 dan 2021, dan menjadi 20 persen mulai tahun pajak 2022. Bagi wajib pajak yang belum menyampaikan SPT Tahunan 2019 sampai dengan akhir Maret 2020 penghitungan dan setoran angsuran PPh pasal 25 sama dengan angsuran pada masa sebelumnya (DJP ;2020). Sebagai akibat dari penurunan tarif tersebut, maka penghitungan dan setoran angsuran pajak penghasilan badan (angsuran PPh pasal 25) untuk tahun 2020 dapat menggunakan tarif sebesar 22 persen.

Pentingnya pajak sebagai penerimaan Negara dan Wajib Pajak sebagai Sumber penerimaan pajak, dimana wajib pajak masih kurang memahami kewajiban-kewajiban perpajakan maka pentingnya dilakukan penelitian terkait tentang " Pemenuhan 


\section{Elastisitas - Jurnal Ekonomi Pembangunan \\ Vol. 3 No. 2, September 2021}

Kewajiban Perpajakan wajib Pajak Badan pada PT. Kamilia Utama Sentosa untuk tahun pajak 2020 yang pelaporan pajaknya akan berakhir pada tanggal 31 April 2021 dengan berpedoman pada peraturan dan per undangundangan perpajakan yang ada.

\section{Perumusan Masalah}

Mengacu pada latar belakang penelitian ,maka dapat dirumuskan masalaha penelitian sebagai berikut :

a. Bagaima pemenuhan keajiban perpajakan PT. Karmila Utama Sentosa pada akhir tahun pajak 2020.

b. Seberapa besara hutang pajak yang harus dibayar berdasarkan koreksi fiskal dengan penerapan tarif 22 persen berdasarkan Perpu No 1 tahun 2020

\section{Tujuan Penelitian}

Adapun tujuan yang ingin dicapai dari hasil penelitian ini adalah sebagai berikut:

1) Untuk mengetahui pemenuhan kewajiban perpajakan (penghitungan, penyetoran dan pelaporan) Wajib Pajak PT. Kamilia Utama Sentosa tahun pajak 2020

2) Untuk menganalisis transaksi keuangan dan koreksi fiskal dalam menentukan besarnya $\mathrm{PPh}$ terutang PT. Kamilia Utama Sentosa dalam pelaporan $\mathrm{PPh}$ Badan pada tahun pajak 2020 yang dilaporkan pada 31 April 2021.

\section{TINJAUAN PUSTAKA}

\section{Pengertian Pajak}

Pajak merupakan iuran rakyat kepada kas negara berdasarkan undang-undang (sehingga dapat dipaksakan) dengan tiada mendapat balas jasa secara langsung. Pajak dipungut berdasarkan norma-norma hukum guna menutup biaya produksi barang-barang dan jasa kolektif untuk mencapai kesejahteraan umum. Jadi, Pajak merupakan hak prerogatif pemerintah, iuran wajib yang dipungut oleh pemerintah dari masyarakat (wajib pajak) untuk menutupi pengeluaran rutin negara dan biaya pembangunan tanpa balas jasa yang dapat ditunjuk secara langsung berdasarkan undang-undang. Adapun definisi pajak menurut para ahli (Waluyo: 2019): a. Menurut Charles E. McLure

Menurut pendapat dari Charles, pajak ialah tanggung jawab keuangan ataupun pajak yang mengenai atas wajib pajak oleh Negara yang fungsinya sederajat dengan negara yang diapakai untuk menjamin beragam macam biaya publik.

b. MenuruT Rochmat Soemitro

Pajak ialah bayaran rakyat kepada negaranya menurut Undang-Undang ataupun pergantan kekayaan dari bagian swasta kepada bagian publik yang dapat diwajibkan dan yang langsung bisa ditentukan serta dipakau untuk membayar keperluan umum.

c. Menurut Djajaningrat

Pajak ialah tangung jawab untuk membagikan sebagian harta benda mereka kepada negara karena keadaan, perihal dan hal yang membagikan kondisi terpilih dimana bayaran tersebut bukanlah sebuah ganjaran, akan tetapi tanggung jawab menurut peraturan Undang-Undang yang sudah diregularkan pemerintah dan dapat diwajibkan.

d. Menurut Rimski Kartika Judisseno Pajak merupakan kewajiban dalam bidang kenegaraan yang berupa pengabdian dan peran aktif warga negara serta anggota masyarakat guna mendanai berbagai segala keperluan Negara dimana berupa pembangunan nasional yang pelaksanaannya tersebut diatur dengan Undang-Undang untuk tujuan kesejahteraan bangsa dan negara.

\section{Fungsi Pajak}

Pajak mempunyai peranan yang sangat penting dalam kehidupan bernegara, khususnya di dalam pelaksanaan pembangunan karena pajak merupakan sumber pendapatan negara untuk membiayai semua pengeluaran termasuk pengeluaran pembangunan. Silahkan disimak berbagai fungsi pajak pada uraian di bawah ini (Online Pajak.Com).

\section{a. Fungsi Anggaran (Budgetair)}

Sebagai sumber pendapatan negara, pajak berfungsi untuk membiayai pengeluaranpengeluaran negara. Untuk menjalankan tugas-tugas rutin negara dan melaksanakan pembangunan, negara 


\section{Elastisitas - Jurnal Ekonomi Pembangunan \\ Vol. 3 No. 2, September 2021}

membutuhkan biaya. Biaya ini dapat diperoleh dari penerimaan pajak. Dewasa ini pajak digunakan untuk pembiayaan rutin seperti belanja pegawai, belanja barang, pemeliharaan, dan lain sebagainya. Untuk pembiayaan pembangunan, uang dikeluarkan dari tabungan pemerintah, yakni penerimaan dalam negeri dikurangi pengeluaran rutin. Tabungan pemerintah ini dari tahun ke tahun harus ditingkatkan sesuai kebutuhan pembiayaan pembangunan yang semakin meningkat dan ini terutama diharapkan dari sektor pajak.

b. Fungsi Mengatur (Regulerend)

Pemerintah bisa mengatur pertumbuhan ekonomi melalui kebijaksanaan pajak. Dengan fungsi mengatur, pajak bisa digunakan sebagai alat untuk mencapai tujuan. Contohnya dalam rangka menggiring penanaman modal, baik dalam negeri maupun luar negeri, diberikan berbagai macam fasilitas keringanan pajak. Dalam rangka melindungi produksi dalam negeri, pemerintah menetapkan bea masuk yang tinggi untuk produk luar negeri.

\section{Sistem Pemungutan Pajak}

Pemungutan pajak di Indonesia menggunakan tiga system (Waluyo:2016) yaitu:

\section{Official Assessment System}

Sistem ini merupakan system pemungutan pajak yang memberi wewenang kepada pemeritah (fiskus) untuk menentukan besarnya pajak yang terutang. Ciri-ciri Official Assssment System adalah sebagai berikut:

a. Wewenang untuk menentukan besarnya pajak terutang berada pada fiskus.

b. Wajib pajak bersifat pasif.

c. Utang pajak timbul setelah dikeluarkan surat ketetapan pajak oleh fiskus.

2. Self Assessment System

Sistem ini merupakan pemungutan pajak yang memberi wewenang, kepercayaan, tanggung jawab kepada Wajib Pajak untuk menghitung, memperhitungkan, membayar, dan melaporkan sendiri besarnya pajak yang harus dibayar.
3 Witholding System

Sistem ini merupakan sistem pemungutan pajak yang memberi wewenang kepada pihak ketiga untuk memotong atau memungut besarnya pajak terutang oleh Wajib Pajak.

\section{Pajak Penghasilan Badan}

Pajak Penghasilan Badan merupakan Pajak yang dikenakan atas penghasilan suatu perusahaan di mana penghasilan yang dimaksud adalah setiap penambahan kemampuan ekonomis yang diterima atau diperoleh oleh Wajib Pajak Badan, baik dari dalam maupun luar negeri, dengan keperluan apapun termasuk misalnya menambah kekayaan, konsumsi, investasi, dan lain sebagainya (Klik Pajak.id).

\section{Subjek dan Objek Pajak Badan antara lain :}

a. Subjek Pajak Badan

Subjek pajak Badan adalah setiap Badan Usaha yang diberikan kewajiban untuk membayar pajak, baik dalam periode bulan maupun tahun dan disetor ke kas negara.

Berdasarkan Undang-Undang

Ketentuan Umum dan Tata Cara Perpajakan (UU KUP), yang termasuk dalam subjek Wajib Pajaak Badan adalah sebagai berikut:
1) Perseroan Terbatas (PT)
2) Perseroan Lainnya
3) Badan Usaha Milik Negara (BUMN)
4) Badan Usaha Milik Daerah (BUMD)

5) Badan Usaha Milik Desa (BUMDes)

6) Firma

7) Kongsi

8) Koperasi

9) Dana Pensiun

10) Persekutuan

11) Perkumpulan

12) Yayasan

13) Organisasi Masyarakat

14) Organisasi Sosial Politik

15) Organisasi lainnya dengan nama dan bentuk apapun

16) Lembaga dan bentuk badan lainnya

17) Kontrak Investasi Kolektif (KIK) 


\section{Elastisitas - Jurnal Ekonomi Pembangunan \\ Vol. 3 No. 2, September 2021}

18) Bentuk Usaha Tetap

b. Objek PPh Badan

Objek PPh Badan adalah penghasilan yang diterima atau diperoleh badan. Bagi Subjek Badan dalam negeri yang menjadi objek $\mathrm{PPh}$ adalah semua penghasilan baik dari dalam maupun dari luar negeri sebagaimana yang tercantum dalam Pasal 4 Ayat (1) Undang-Undang PPh yang meliputi:

1) Hadiah dari kegiatan dan penghargaan.

2) Laba usaha.

3) Keuntungan karena penjualan atau karena pengalihan harta (selain tanah dan bangunan).

4) Penerimaan kembali pembayaran pajak yang telah dibebankan sebagai biaya.

5) Bunga, termasuk premium, diskonto, dan imbalan karena jaminan pengembalian utang.

6) Dividen.

7) Royalti atau imbalan atas penggunaan hak.

8) Sewa dan penghasilan lain sehubungan dengan penggunaan harta.

9) Keuntungan karena pembebasan utang, kecuali sampai dengan jumlah tertentu yang ditetapkan.

10) Peraturan Pemerintah.

11) Keuntungan karena selisih kurs mata uang asing.

12) Selisih lebih karena penilaian kembali aktiva tetap.

13) Iuran yang diterima perkumpulan dari anggotanya yang terdiri dari Wajib Pajak yang menjalankan usaha atau pekerjaan bebas.

14) Penghasilan dari usaha berbasis syariah.

15) Surplus Bank Indonesia

\section{Rekonsiliasi Fiskal}

Rekonsiliasi Fiskal adalah proses penyesuaian atas laba akuntansi yang berbeda dengan ketentuan fiskal untuk menghasilkan penghasilan neto atau laba yang sesuai dengan ketentuan perpajakan. Dengan melakukan proses rekonsiliasi fiskal ini maka Wajib Pajak tidak perlu membuat pembukuan ganda, melainkan cukup membuat 1 pembukuan yang didasari SAK-ETAP. Setelah dibuatkan rekonsiliasi fiskal untuk mendapatkan laba fiskal Penghasilan Kena Pajak (PKP) yang akan digunakan sebagai sebagai dasar penghitungan $\mathrm{PPh}$. Koreksi fiskal tersebut dapat dibedakan antara beda tetap dan beda waktu.

Rekonsiliasi fiskal dilakukan oleh wajib pajak yang pembukuannya menggunakan pendekatan akuntansi komersial, yang bertujuan untuk mempermudah mengisi SPT tahunan $\mathrm{PPh}$ dan menyusun laporan keuangan fiskal yang harus dilampirkan pada saat menyampaikan SPT tahunan PPh.

Koreksi fiskal dapat berupa koreksi positif dan koreksi negatif. Koreksi positif terjadi apabila laba menurut fiskal bertambah. Koreksi positif biasanya dilakukan akibat adanya hal-hal berikut:

1) Beban yang tidak diakui oleh pajak/ non deductible expense ( Pasal 9 ayat $1 \mathrm{UU}$ $\mathrm{PPh}$ )

2) Penyusutan komersial lebih besar dari penyusutan fiskal.

3) Amortisasasi komersial lebih besar dari amortisasi fiskal.

4) Penyesuaian fiskal positif lainnya. Koreksi negatif terjadi apabila laba menurut fiskal berkurang, koreksi negatif biasanya dilakukan akibat adanya hal-hal berikut:

1) Penghasilan yang tidak termasuk objek pajak (Pasal 4 ayat $3 \mathrm{UU} \mathrm{PPh}$ )

2) Penghasilan yang dikenakan $\mathrm{PPh}$ bersifat final (Pasal 4 ayat 2 UU PPh)

3) Penyusutan komersial lebih kecil daripada penyusutan fiskal

4) Amortisasi komersial lebih kecil daripada amortisasi fiskal

5) Penghasilan yang ditangguhkan pengakuannya

6) Penyesuaian fiskal negatif lainnya.

\section{Penghitungan}

Sebagai Wajib Pajak Badan, harus mengikuti ketentuan penghitungan pajak sesuai dengan ketentuan perundangundangkan, (djp online).

1. Menghitung Penghasilan Kena Pajak 


\section{Elastisitas - Jurnal Ekonomi Pembangunan \\ Vol. 3 No. 2, September 2021}

\begin{abstract}
Langkah-langkah
untuk mendapatkan besaran Penghasilan Kena Pajak adalah sebagai berikut:
\end{abstract}

a. Hitung seluruh Penghasilan yang diterima atau diperoleh dalam satu tahun pajak secara fiskal.

b. Kurangi dengan biaya-biaya yang meliputi seluruh biaya yang secara langsung atau tidak langsung berkaitan dengan kegiatan usaha, antara lain: biaya pembelian bahan; biaya berkenaan dengan pekerjaan atau jasa (gaji, tunjangan dsb), biaya bunga, biaya sewa, royalty, biaya perjalanan, biaya pengolahan limbah, premi asuransi, biaya promosi dan penjualan, biaya administrasi. Jangan lupa untuk mengurangkan biaya penyusutan dan amortisasi.

c. Perhatikan biaya-biaya yang tidak dapat dikurangkan sebagaimana di atur dalam perundangan perpajakan beserta aturan turunannya. Keluarkan biaya-biaya tersebut dalam penghitungan Penghasilan Kena Pajak.

Apabila penghasilan bruto setelah pengurangan biaya-biaya didapat kerugian sehingga tidak terdapat Penghasilan Kena Pajak kerugian tersebut dikompensasikan dengan penghasilan mulai tahun pajak berikutnya berturutturut sampai dengan 5 (lima) tahun.

\section{Tarif}

Untuk mendapatkan nominal $\mathrm{PPh}$ terutang atau pajak penghasilan yang dibayarkan, wajib pajak dapat mengalikan penghasilan kena pajak dengan tarif pajak yang berlaku.

Berdasarkan Pasal 17 ayat (1) bagian b UU No. 36 Tahun 2008 tentang Pajak Penghasilan, tarif pajak yang dikenakan kepada badan adalah $25 \%$. Besar tarif ini berlaku sampai tahun pajak 2019.

Selanjutnya, berdasarkan Peraturan

Pemerintah Pengganti Undang-Undang Republik Indonesia Nomor 1 Tahun 2020, pemerintah menurunkan tarif umum $\mathrm{PPh}$ Badan menjadi 22\% untuk tahun 2020 dan 2021, lalu menjadi 20\% pada tahun 2022.

\section{METODE PENELITIAN}

\section{Jenis Penelitian}

Penelitian ini menggunakan metode kasus (case study) yaitu suatu penelitian yang dilakukan secara intensif, terperincidan mendalam terhad suatu organisme (individu) lembaga atau gejala tetentu dengan daerah atau subyek yang sempit. (Arikunto: 2013). Dalam penelitian ini adalah kasus yang terdapat pada perusahaan PT. Kamilia Utama Sentosa yang berkaitan dengan data-data transaksi perusahaan dalam tahun 2020 serta tentang kewajiban pelaporan perpajakan pada akhir tahun pajak tahun 2020 .

\section{Tempat Dan Waktu Penelitian}

Penelitian ini dilaksanakan pada bulan Februari tahun 2021 dengan mengambil tempat penelitian pada PT. Kamilia Utama Sentosa yang beramat di jalan Segara Anak no 45 kecamatan Ampenan Kota Mataram.

\section{Teknik Pengumpulan Data}

Penelitian ini bersifat deskriptif dengan mengambil data-data primer dan sekunder pada perusahaan yang berupa data hasil observasi, wawancara dan dokumentasi yaitu sebagai berikut :

1. Observasi, yaitu melakukan pengamatan langsung ke perusahaan yang diteliti untuk mengumpulkan data sesuai dengan informasi yang diperlukan dalam penelitian.

2. Wawancara adalah proses pengumpulan data yang dilakukan dengan cara mengajukan pertawnyan secara langsung dan sistimatis untuk memperoleh informasi data yang dibutuhkan dalam penelitian ini seperti informasi transaksi keuangan perusahaan.

3. Dokumentasi adalah teknik pengumpulan data dengan cara menggali informasi berdasarkan data-data yang ada pada dokumentasi perusahaan, seperti dokumen transaksi (bukti transaksi), laporan neraca dan laporan laba/rugi perusahaan tahun 2020.

Teknik Analisis Data

Analisis data dilakukan secara kualitatif deskriptif yaitu dengan 


\section{Elastisitas - Jurnal Ekonomi Pembangunan \\ Vol. 3 No. 2, September 2021}

mengupulkan informasi data yang dilakukan , kemudian penyajian data, reduksi data dan simpulan verifikasi data.

Penghitungan PPh badan dilakukan dengan menggunakan formulasi sebagai berikut :

a. Kurang dari Rp 4,8 milyar Penghasilan Kotor: Tarif pajak bruto $=50 \%$ x $25 \% \mathrm{x}$ PKP (Penghasilan Kena Pajak)

b. Lebih dari Rp 4,8 Milyar sampai dengan Rp 50 Milyar PPh $=[(50 \%$ x $25 \%) \mathrm{x}$ Penghasilan Kena Pajak yang memperoleh Fasilitas ] $+25 \% \mathrm{x}$ Penghsilan Kena Pajak Tidak Memperoleh Fasiltas)

c. Peraturan Pemerintah Pengganti UndangUndang Republik Indonesia Nomor 1 Tahun 2020 tarif umum $\mathrm{PPh}$ Badan menjadi $22 \%$ untuk tahun 2020

\section{HASIL DAN PEMBAHASAN}

\section{Gambaran Umum PT. Kamilia Utama Sentosa \\ PT. Kamilia Utama Sentosa} merupakan perusahaan yang bergerak di bidang instalasi listrik dan beralamat di Jln. Segara Anak No. 45 Ampenan Kota Mataram. Erusahaan ini melaksakan pekerjaan proyek-proyek pemerintah mapun suasta baik melalui tender maupun pengadaan material untuk kebutuhan kantor pemerintah maupun BUMN seperti Dinas Pekerjaan Umum, Perusahaan Listrik Negara dan lain sebgainya.

Ada akhir tahun PT. Kamilia Utama Sentosa melakukan perhitungan-perhitungan keuangan atas semua transaksi yang dilakukan terhadap kegiatan pekerjaan perusahaan pada tahun 2020 yang akan dijadikan dasar dalam melakukan perhitungan pajak akhir tahun yaitu pajak penghasilan badan (PPh Badan) yang akan dikenakan atas seluruh keuntungan /laba perusahaan pada tahun berjalan yaitu laba tanun 2020, yang akan dihitung dan dilaporakan pada akhir tahun pajak tahun 2020.

Berdasarkan PP 45/2019 Pasal 27 ayat (1) Apabila wajib pajak memperoleh penghasilan yang dikenakan pajak secara Pembukuan terpisah tersebut dimaksudkan agar wajib pajak dapat
Penghitungan pajak penghasilan terutang PT. Kamilia Utama Sentosa dilakukan dengan mengacu pada undangundang perpajakan yaitu mengacu pada peraturan pemerintah, yaitu Pasal 31E UU $\mathrm{PPh}$ dan Peraturan Pemerintah Pengganti Undang-Undang Republik Indonesia Nomor 1 Tahun 2020, pemerintah menurunkan tarif umum $\mathrm{PPh}$ Badan menjadi $22 \%$ untuk tahun 2020 dan 2021, lalu menjadi $20 \%$ pada tahun 2022.

Sebagai wajib Pajak Badan PT. Kamilia Utama Sentosa dituntut untuk melaporkan pajak terutangnya dengan melampirkan Neraca, Laporan Rugi/Laba dan rekonsiliasi fiskal untuk neraca per 31 desember 2020. Untuk melakukan penghitungan pajak ini maka perusahan harus dapat menunjukkan bukti transaksi selama tahun 2020 dan keterangan-keterangan lainnya berkaitan dengan informasi keuangan perusahaan, seperti gaji, pembelian barangbarang kantor, transport dan penghailan perusahaan dari pekerjaan yang dilakukan selama tahun 2020. Hal ini dilakukan untuk pemenuhan keuajiban perpajakan pada setiap akhir tahun pajak.

\section{Prosedur pemenuhan kewajiban (penghitungan, penyetoran, dan pelaporan) Wajib Pajak PT. Kamilia Utama Sentosa}

\section{Penghitungan Pajak Penghasilan}

Pada tahun 2020 PT. Kamilia Utama Sentosa memiliki peredaran usaha sebesar Rp. 3.487.058.460. yang terdiri dari penghasilan yang bersifat final sebesar Rp. 1.178.257.750 dan penghasilan tidak final sebesar $\mathrm{Rp}$. 2.308.800.710.

Karena peredaran bruto PT. Kamilia Utama Sentosa di tahun pajak 2019 sebesar Rp. 9.687.761.000. atau melebihi Rp. 4.800.000.000. maka perhitungan pajak terutang tahun 2020 sesuai dengan pasal 17 dan 31E Undang-Undang No 36 Tahun 2008 tentang pajak penghasilan.

final dan nonfinal, maka wajib pajak tersebut wajib menyelenggarakan pembukuan secara terpisah.

memisahkan penghasilan beserta biaya yang dikeluarkan untuk memperoleh penghasilan 


\section{Elastisitas - Jurnal Ekonomi Pembangunan \\ Vol. 3 No. 2, September 2021}

tersebut. Namun, apabila biaya tersebut tidak dapat dipisahkan untuk penghasilan yang pajaknya final dan tidak final (dapat juga penghasilan yang objek pajak atau bukan objek pajak) maka pembebanannya dialokasikan secara proporsional.

Perlakuan penghitungan pajak terutang ajib pajak badan dilakukan dengan melihat semua komponen pembayaran yang dilakukan dalam transaksi selama satu tahun, baik itu yang berhubungan dengan pembayaran aktivitas perusahaan itu sendiri maupun pembayaran diluar dri aktivitas perusahaan yang ditunjukkan dengan bukti pembayaran baik berupa kuitansi, nota maupun bukti lainnya yang dibenarkan menurut peraturan yang ada. Dari bukti-bukti pengeluaran yang dilakukan oleh perusahaan dalam hal ini PT. Kamilia Utama Sentosa di cocokkan dengan pembukuan dan neraca yang dibuat, barulah dibuat koreksi fiskal untuk mengetahui laba sebelum pajak dan setelah pajak sehingga dapat dihitung besarnya $\mathrm{PPh}$ terutang sesuai dengan peraturan perundangan yang ada.

Tabel 3. Laporan laba rugi atas penghasilan yang bersifat Final

\section{PT. KAMILIA UTAMA SENTOSA \\ LAPORAN LABA RUGI (PPH FINAL) \\ PER 31 DESEMBER 2020}

\begin{tabular}{|c|c|c|c|}
\hline \multicolumn{2}{|l|}{ PENERIMAAN/ OMSET } & Rp. & 1.178 .257 .750 \\
\hline \multicolumn{4}{|l|}{ HARGA POKOK PENJUALAN : } \\
\hline Pembelian material dar Rp. & 877.490 .114 & & \\
\hline HPP & & Rp. & $(877.490 .114)$ \\
\hline LABA BRUTO & & Rp. & 300.767 .636 \\
\hline \multicolumn{4}{|l|}{ BIAYA ADMINISTRASI \& UMUM } \\
\hline Biaya Gaji Karyawan \& ' Rp. & 156.968 .806 & & \\
\hline Biaya BBM & 5.959 .178 & & \\
\hline Biaya Registrasi \& Periz Rp. & 6.050 .158 & & \\
\hline Biaya Listrik, Air, Telpor Rp. & 2.592 .925 & & \\
\hline Biaya ATK,Jilid \& Fotoc Rp. & 960.383 & & \\
\hline Biaya Penyusutan & 4.321 .542 & & \\
\hline Biaya Administrasi Bank Rp. & 1.786 .389 & & \\
\hline Biaya Bunga Pinjaman Rp. & 12.666 .588 & & \\
\hline Biaya Administrasi PLN Rp. & 44.064 .735 & & \\
\hline \multicolumn{2}{|c|}{ Total Biaya Administrasi \& umum } & Rp. & $(235.370 .704)$ \\
\hline \multicolumn{2}{|l|}{ LABA NETTO } & Rp. & 65.396.932 \\
\hline \multicolumn{2}{|l|}{ Pendapatan Bunga } & Rp. & 202.269 \\
\hline \multicolumn{2}{|l|}{ PAJAK PENGHASILAN } & Rp. & 23.565.155 \\
\hline \multicolumn{2}{|l|}{ LABA NETTO } & Rp. & 42.034 .046 \\
\hline
\end{tabular}

Sumber: PT. Kamilia Utama Sentosa 2020 


\title{
Elastisitas - Jurnal Ekonomi Pembangunan
}

Vol. 3 No. 2, September 2021

Tabel 4. Laporan Laba rugi atas penghasilan yang bersifat non final

\author{
PT. KAMILIA UTAMA SENTOSA \\ LAPORAN LABA RUGI (PPH NON FINAL)
}

PER 31 DESEMBER 2020

\begin{tabular}{|c|c|c|c|}
\hline PENERIMAAN/ OMSET & & Rp. & 2.308 .800 .710 \\
\hline \multicolumn{4}{|l|}{ HARGA POKOK PENJUALAN : } \\
\hline Pembelian material dar Rp. & 1.102 .482 .286 & & \\
\hline HPP & & Rp. & $(1.102 .482 .286)$ \\
\hline LABA BRUTO & & Rp. & 1.206.318.424 \\
\hline \multicolumn{4}{|l|}{ BIAYA ADMINISTRASI \& UMUM } \\
\hline Biaya Gaji Karyawan \& ’ Rp. & 542.033 .694 & & \\
\hline Biaya BBM & 19.025 .522 & & \\
\hline Biaya Registrasi \& Periz Rp. & 25.198 .342 & & \\
\hline Biaya Listrik, Air, Telpor Rp. & 15.664 .975 & & \\
\hline Biaya ATK,Jilid \& Fotoc Rp. & 2.518 .517 & & \\
\hline Biaya Penyusutan & 19.428 .458 & & \\
\hline Biaya Administrasi Bank Rp. & 9.359 .043 & & \\
\hline \multirow[t]{2}{*}{ Biaya Bunga Pinjaman } & 83.408 .412 & & \\
\hline & 13.619 .650 & & \\
\hline \multicolumn{2}{|l|}{ Total Biaya Administrasi \& umum } & Rp. & $(730.256 .612)$ \\
\hline LABA NETTO & & Rp. & 476.061 .811 \\
\hline Pendapatan Bunga & & Rp. & 6.923 .372 \\
\hline PAJAK PENGHASILAN & & Rp. & 62.082 .451 \\
\hline LABA NETTO & & Rp. & 420.902 .732 \\
\hline
\end{tabular}

Keterangan tambahan:

1. Biaya BBM untuk keperluan pribadi direktur sebesar Rp. 11.497.700

2. Biaya listrrik, air, telpon direktur sebesar Rp. 9.100 .100 


\section{Elastisitas - Jurnal Ekonomi Pembangunan \\ Vol. 3 No. 2, September 2021}

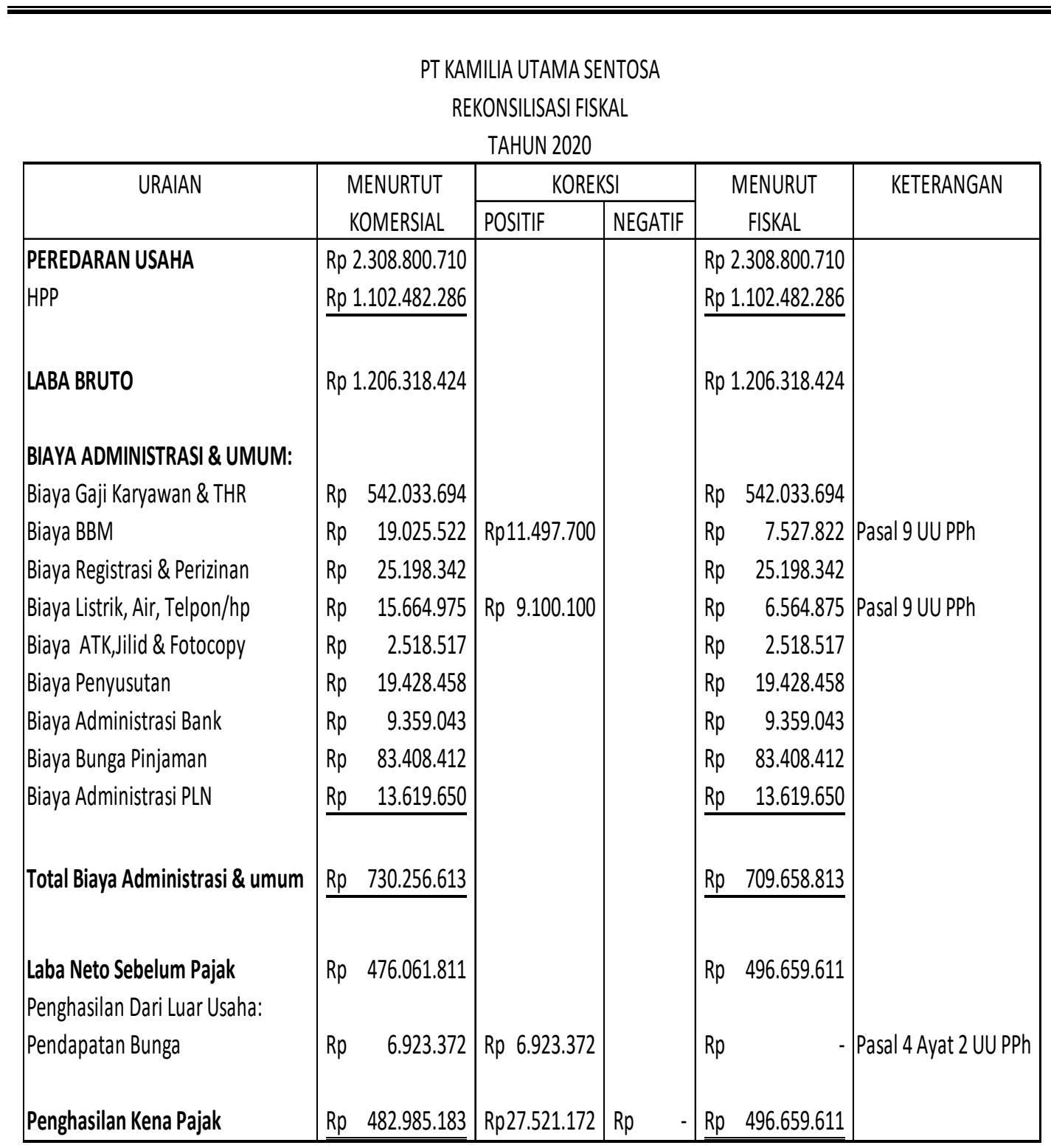

Sumber : Data enelitian di olah.

Dari gambar 6 di atas dapat dilihat bahwa proses penghitungan $\mathrm{PPh}$ terutang yang dilakukan tidak sesuai dengan Peraturan Pemerintah Pengganti Undang-Undang Republik Indonesia Nomor 1 Tahun 2020, mengenai penurunan tarif umum PPh Badan menjadi 22\% untuk tahun 2020 dan 2021. Oleh karena itu dilakukan perbaikan penghitungan $\mathrm{PPh}$ terutang sesuai dengan Peraturan Pemerintah Pengganti UndangUndang Republik Indonesia Nomor 1 Tahun 2020 yaitu sebagai berikut: 


\section{Elastisitas - Jurnal Ekonomi Pembangunan \\ Vol. 3 No. 2, September 2021}

\begin{tabular}{|c|c|c|c|}
\hline \multicolumn{4}{|l|}{ PENGHITUNGAN PPh TERUTANG } \\
\hline \multirow[t]{2}{*}{ PKP yang mendapat Fasilitas: } & $\underline{4.800 .000 .000 \times 496.659 .611}$ & $\mathrm{Rp}$ & 683.661 .074 \\
\hline & 3.487 .058 .460 & & \\
\hline PKP yang tidak mendapat fasilitas: & $496.659 .611-683.661 .074$ & $-R p$ & 187.001 .463 \\
\hline \multirow[t]{3}{*}{ PPh Terutang } & $(50 \% \times 22 \%) \times 683.661 .074$ & $\mathrm{Rp}$ & 75.202 .718 \\
\hline & $(25 \% \times(-187.001 .463))$ & $-\underline{R p}$ & 41.140 .321 \\
\hline & & $\mathrm{Rp}$ & 34.062.397 \\
\hline \multicolumn{4}{|l|}{ Kredit Pajak: } \\
\hline PPh Pasal 22 & & $\mathrm{Rp}$ & 3.224 .973 \\
\hline PPh Pasal 23 & & $\mathrm{Rp}$ & 55.812 .302 \\
\hline PPh Pasal 25 & & $\underline{\mathrm{Rp}}$ & 2.880 .069 \\
\hline Jumlah Kredit Pajak & & $\mathrm{Rp}$ & 61.917 .344 \\
\hline PPh yang lebih dibayar (PPh Pasal 28A) & & $\mathrm{Rp}$ & 27.854 .947 \\
\hline
\end{tabular}

Setelah dilakukan penghitungan PPh terutang sesuai dengan peraturan perundang-undangan yang berlaku seperti yang tertera pada tabel, maka dapat diketahui PT Kamilia Utama Sentosa memiliki PPh lebih bayar sebesar Rp. 27.854.947dan seharusnya tidak mengalami PPh kurang bayar seperti yang telah dihitung oleh konsulltan.

\section{Pelaporan SPT Tahunan}

Konsultan melakukan pelaporan SPT tahunan menggunakan E-Form, karena memiliki kelebihan daripada e-filling yaitu e-form mengombinasikan fitur daring dan offline. Maksud dari hal tersebut adalah untuk bisa mengunduh formulir SPT perangkat yang digunakan wajib pajak diharuskan tersambung internet, selanjutnya apabila telah berhasil diunduh wajib pajak dapat mengisinya secara offline atau tidak harus tersambung ke jaringan internet lagi. Koneksi ke jaringan internet pada E-form hanya dibutuhkan saat pengunduhan dan pengunggahan formulir SPT yang telah diisi dengan benar, lengkap, dan jelas oleh wajib pajak.

Bukti lapor melaluui E-Form dapat dilihat pada lampiran dan SPT Tahunan Formulir 1771 yang sudah diisi oleh konsultan yang dapat dilihat pada lampiran. Dengan demikian konsultan sebagai kuasa pajak atas PT. Kamilia Utama Sentosa sudah melaksanakan kewajibannya dengan baik.

\section{KESIMPULAN DAN SARAN}

Prosedur Pemenuhan Kewajiban Wajib Pajak Badan meliputi penghitungan, penyetoran, dan pelaporan SPT Tahunan sudah sesuai dengan UU dan Ketentuan Umum Dan Tata Cara Perpajakan yang berlaku, dimana PT. Kamilia Utama Sentosa telah membayar dan melaporkanPPh terutang Rp 34.062.397 - Rp 61.917.344 (kredit pajak $\mathrm{PPh}$ pasal $22,23,25)$ maka terjadi $\mathrm{PPh}$ yang lebih dibayar sebesar $\mathrm{Rp}$ 27.854.947 (PPh pasal 28A). Kelebihan pembayaran pajak tersebut oleh pihak perusahaan dapat di minta kembali (restitusi) karena jumlah pajak yang dibayarkan lebih besar dari pada jumlah pajak yang terutang. Dalam pelaporan SPT Tahunan PT. Kamilia Utama Sentosa telah melaporkan pajaknya dengan menggunakan fasilitas internet di mana penyampaian SPT secara elektronik ini dapat dilakukan melalui fasilitas e-Filing. 


\section{REFERENSI}

Anonim, 2021. Peraturan pajak dan peraturan menteri keuangan. Diunduh pada tanggal 17 Februari 2021, Jam 19:20. https://perpajakan.ddtc.co.id

Anonim, 2021. Fungsi pajak. Diunduh pada tanggal 18 Februari 2021 jam 22:39. https://www.pajak.go.id/id

Anonim, 2021. Tata cara pembayaran dan penyetoran pajak. Diunduh pada tanggal 20 April 2021, jam 11:34. https://www.pajak.go.id

Anonim, 2021. Mekanisme Penghitungan Pajak Penghasilan Badan. Diunduh pada tanggal 29 April 2021, jam 14:20. https://pajak.go.id/id

Anonim, 2021. Undang-undang nomor 28 tahun 2007, Diunduh pada tanggal 20 Februari 2021, jam 21:00. https://pajak.go.id/id

Bahari, Saepul. 2017. Risalah Mahasiswa Hukum. Bandung, Rasi Terbit. Diunduh pada tanggal 18 Februari 2021 jam 20:30. http://google.book.com
Kasiyanto, Agus. 2014. Proses Penyelsaian Sengketa Pajak Indonesia.Surabaya. Jakad Media Publishing. Diunduh pada tanggal 17 Februari 2021 jam 14:20. http://google.book.com

Mardiasmo, 2018," Perpajakan "edisi revisi 2018, ANDI, Yogyakarta.

Nurmantu, Safitri, 2005, "Pengantar Perpajakan" Edisi 3. Jakarta. Granit. Diunduh pada tanggal 17 Februari 2021 jam 20:20). http://google.book.com

Waluyo. 2017, "Perpajakan Indonesia" Edisi 12 Buku 1. Jakarta. Salemba Empat.

Resmi, Siti, 2014, "Perpajakan" Teori dan Kasus Buku 1 Edisi 8. Jakarta. Salemba Empat.

Tjahjono, Achmad, 2009. "Perpajakan" Edisi Keempat. Yogyakarta. UPP STM

Agoes, Sukrisno, 2013. Akuntansi Perpajakan. Jakarta, Salemba Empat 